\title{
New African frontiers: transnational families in neoliberal capitalism Introduction
}

\author{
Chelsie Yount-André
}

Neoliberal policies that foster the international flow of commodities but hinder the movement of people have transformed the ways in which kin across continents struggle to assure the reproduction of households in Africa. The austerity measures of structural adjustment diminished the ranks of civil servants and decimated state investment in infrastructure, education and social welfare systems. This themed section attests to a multiplication of educational and migratory trajectories West Africans pursue, each path seemingly more precarious than the last. Focusing on everyday moments of family life achieved across borders, these articles show how global transformations have placed increasing pressure on migrants, while pushing those in Africa to find new ways to connect with and send family members abroad.

Migration has long shaped family life in West Africa. In the decades since Kopytoff and his collaborators (1987) investigated the reproduction of 'traditional African societies' across intra-African frontiers, scholars have demonstrated how practices glossed as 'traditional' continue to provide Africans with tools for managing global structures of inequality that accompany neoliberal capitalism (Diouf 2000; Babou 2002; Guyer 2004; Bledsoe and Sow 2011; Buggenhagen 2012; Coe 2014; Cole 2014; Moya 2017). The three articles presented here explore how families draw on long-standing kinship strategies to manage contemporary economic volatility. They highlight the ways in which global inequalities are made palpable in everyday familial relations, considering how relatives' attempts to manage their resources reproduce certain socio-economic connections but curtail other kinship relations.

Each article takes family homes in Senegal as a point of departure, and follows research participants' connections to France and Italy, the US and Canada. Building on the work of scholars who have advocated for the examination of Africa and its diaspora as a single unit (Sargent and Larchanché-Kim 2006; Fesenmyer 2012; Cole 2014; Coe 2014; Kleinman 2014; Groes-Green 2014; Neveu Kringelbach 2015; Feldman-Savelsberg 2016; Kea 2017; Hannaford 2017), each of these articles draws on multisited fieldwork that spans continents. Cole and Groes' notion of 'affective circuits' proves particularly apt here, for its capacity to 'capture the potential for disconnection and conflict', illustrating that the networks 'through which objects, ideas, and people move are subject to regulation, slow downs, and blockage' (2016: 7). Focusing on intimate

Chelsie Yount-André is a postdoctoral fellow in anthropology at the University of Montpellier, France, at the CIRAD research centre. She received her $\mathrm{PhD}$ in anthropology from Northwestern University and the EHESS, Paris in 2017. Her work explores economics and morality in transnational Senegalese families with a particular focus on children, language and food sharing. Email: chelsie.yount@cirad.fr

(C) International African Institute 2018 
relationships that organize resource redistribution, these articles draw attention to local frictions that impede flows of support between relatives in Africa and abroad. Indeed, as James Ferguson noted, ethnographic material from Africa makes clear that even in globalized economies, capital does not 'flow' but rather 'hops', 'efficiently connecting the enclaved points in the network while excluding (with equal efficiency) the spaces that lie between the points' (2006: 47).

These articles shed light on the processes through which capital hops from one person to another within families. While the resources migrants send to their families in Africa may appear to 'flow' when analysed on a global scale, close examination of socio-economic relations among transnational kin reveal 'family' to be an uneven terrain, in which certain people and social relations are favoured for redistribution and others are regularly skipped over. But contrary to narratives common in West Africa of migrants who become 'individualistic' and 'forget' their kin back home, these articles demonstrate how processes of exclusion can take place through the very idioms of kinship and channels of rank-based redistribution that are valued in Africa and are lauded as generous displays of solidarity and largesse. These articles show how even choices to avoid providing material care are carried out according to value-laden notions of responsibility towards unequally positioned kin: migrants who invest more in a full sister's children than they do in a half-brother's, who offer more substantial gifts to a crosscousin abroad than to a parallel cousin nearby, and who strategically delay requests by avoiding calls, rather than refusing to help outright.

Grysole's article shows how the privatization and diversification of schooling options in Senegal are linked to migration paths that parents imagine are possible for children, so that school choices represent a gamble that implicates family members across continents. Hannaford provides a vivid portrayal of the ways in which neoliberal policies and new technologies have altered the material conditions of long-distance intimate connections. She traces connections between Dakar's disappearing cybercafés and transnational spouses' intensifying expectations of emotional and financial availability, as migrants are increasingly expected to provide services the state once assured. Yount-André demonstrates how family members in Senegal invest in the material care of children in France, forging particularly close relations between educated, francophone branches of transnational families.

Articles in this section highlight the place of children in transnational families, both the agency youth exercise in making connections with distant kin and children's role as a locus of adult efforts. In West Africa, children's material needs and upbringing have long been managed by many adults, including but not limited to their birth parents (see Bledsoe et al. 1988; Shipton 2007; Whitehouse 2012). These articles show how children in transnational families provide a means through which adults attempt to reinforce relationships, legitimize requests for funds, and invest in the future. Focusing on 'practical kinship' (Bourdieu 1972), Grysole and Yount-André offer theoretical approaches to grappling with family relations that transcend continents. Drawing respectively on Weber's (2002) notion of maisonnée and Agha's (2007) meta-semiotics of kinship, they show how transnational families encompass multiple normative views of kinship and the economic expectations it entails. Hannaford considers West Africa's long history of mobility to theorize what is new and noteworthy about African long-distance intimacy in neoliberalism. 
These articles make clear the continued relevance of the notion of 'wealth in people' (Guyer 1993; Guyer and Belinga 1995) in neoliberal capitalism. Status as a successful migrant, or an otherwise 'big' person - remains contingent on redistribution. Further, these articles highlight the fact that the reproduction of African households depends on members' capacity to maintain close connections with those abroad. Efforts to achieve contemporary figures of success, manifest in digital devices and diplomas recognized internationally, are ultimately aimed at the creation of a new generation with the means to support dependants. This section provides an innovative look at questions of family, reciprocity and imbricated emotional and material relations, examined relative to the economic uncertainties that characterize neoliberal capitalism in West Africa.

\section{References}

Agha, A. (2007) Language and Social Relations. Cambridge: Cambridge University Press.

Babou, C. A. (2002) 'Brotherhood solidarity, education and migration: the role of the Dahiras among the Murid Muslim community of New York', African Affairs 101 (403): 151-70.

Bledsoe, C. and P. Sow (2011) 'Back to Africa: second chances for the children of West African immigrants', Journal of Marriage and Family 73 (4): 747-62.

Bledsoe, C., D. Ewbank and U. Isiugo-Abanihe (1988) 'The effect of child fostering on feeding practices and access to health services in rural Sierra Leone', Social Science and Medicine 6: 627-36.

Bourdieu, P. (1972) Esquisse d'une Théorie de la Pratique: précédé de 'Trois Études d'Ethnologie Kabyle'. Geneva: Librairie Droz.

Buggenhagen, B. (2012) Muslim Families in Global Senegal: money takes care of shame. Bloomington IN: Indiana University Press.

Coe, C. (2014) The Scattered Family: parenting, African migrants, and global inequality. Chicago IL: University of Chicago Press.

Cole, J. (2014) 'Working mis/understandings: the tangled relationship between kinship, Franco-Malagasy binational marriages, and the French state', Cultural Anthropology 29 (3): 527-51.

Cole, J. and C. Groes (eds) (2016) Affective Circuits: African migrations to Europe and the pursuit of social regeneration. Chicago IL: University of Chicago Press.

Diouf, M. (2000) 'The Senegalese Murid trade diaspora and the making of a vernacular cosmopolitanism', Public Culture 12 (3): 679-702.

Feldman-Savelsberg, P. (2016) 'Forging belonging through children in the BerlinCameroonian diaspora' in J. Cole and C. Groes (eds), Affective Circuits: African migrations to Europe and the pursuit of social regeneration. Chicago IL: University of Chicago Press.

Ferguson, J. (2006) Global Shadows: Africa in the neoliberal world order. Durham NC: Duke University Press.

Fesenmyer, L. E. (2012) 'Relative distance: practices of relatedness among transnational Kenyan families'. PhD thesis, University of Oxford.

Groes-Green, C. (2014) 'Journeys of patronage: moral economies of transactional sex, kinship, and female migration from Mozambique to Europe', Journal of the Royal Anthropological Institute 20 (2): 237-55. 
Guyer, J. I. (1993) 'Wealth in people and self-realization in Equatorial Africa', Man 28 (2): 243-65.

Guyer, J. I. (2004) Marginal Gains: monetary transactions in Atlantic Africa. Chicago IL: University of Chicago Press.

Guyer, J. I. and S. Belinga (1995) 'Wealth in people as wealth in knowledge: accumulation and composition in Equatorial Africa', Journal of African History 36 (1): 91-120.

Hannaford, D. (2017) Marriage without Borders: transnational spouses in neoliberal Senegal. Philadelphia PA: University of Pennsylvania Press.

Kea, P. (2017) 'Photography, care and the visual economy of Gambian transatlantic kinship relations', Journal of Material Culture 22 (1): 51-71.

Kleinman, J. (2014) 'The path between two points: Malian adventures in France', Transition 113 (1): 25-43.

Kopytoff, I. (ed.) (1987) The African Frontier: the reproduction of traditional African societies. Bloomington IN: Indiana University Press.

Moya, I. (2017) De l'Argent aux Valeurs: femmes, économie, société à Dakar. Nanterre: Éditeur Publications de la Société d'Ethnologie.

Neveu Kringelbach, H. (2015) 'Gendered educational trajectories and transnational marriage among West African students in France', Identities 22 (3): 288-302.

Sargent, C. F. and S. Larchanché-Kim (2006) 'Liminal lives: immigration status, gender, and the construction of identities among Malian migrants in Paris', American Behavioral Scientist 50 (1): 9-26.

Shipton, P. (2007) The Nature of Entrustment: intimacy, exchange, and the sacred in Africa. New Haven CT: Yale University Press.

Weber, F. (2002) 'Pour penser la parenté contemporaine' in D. Debordeaux and P. Strobel (eds), Les Solidarités Familiales en Question: entraide et transmission. Collection Droit et Société. Paris: LGDJ.

Whitehouse, B. (2012) Migrants and Strangers in an African City: exile, dignity, belonging. Bloomington IN: Indiana University Press. 